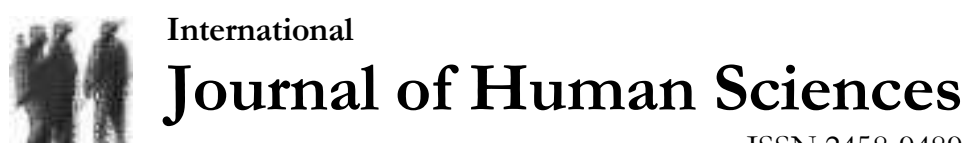 \\ ISSN:2458-9489
}

Volume: 16 Issue: 1 Year: 2019

\section{Evaluating the open admission practice in vocational colleges (Kirklareli University case) ${ }^{1}$}

\author{
Isil Tuzun Arpacioglu ${ }^{2}$ \\ Ertug Can $^{3}$ \\ Fatma Oya Aktas ${ }^{4}$
}

\begin{abstract}
With a regulation made in 2001, vocational and technical secondary education graduates were given the right to enroll to vocational colleges without taking the national central exam. However, this regulation was repealed in 2016. If the students are placed in an associate degree program in the same field, additional points are added to the points gained from central examination. The purpose of this research is to evaluate the open admission practice which had been going on for more than fifteen years and the abolition of this practice according to the opinions of the academics who work in vocational colleges of Kirklareli University. The data of the research were collected with the help of four open ended questions in written form, with the qualitative research method. The abolition of the open admission practice is evaluated as a positive development by academic stuff of Kirklareli University, in terms of the quality of education and employability. The research findings show that eliminating the open admission practice is a positive practice. According to the findings of the study, was evaluated positively the removal of the open admission practice. Inter-agency cooperation on the issue can be useful.
\end{abstract}

Keywords: vocational colleges; vocational and technical education; open admission practice; scoring system; employability.

\section{Introduction}

The first vocational colleges in Turkey, operating under the Ministry of Education, opened in 1974-1975 academic year. Vocational colleges were later incorporated into the Higher Education Council (YÖK, 2010). Vocational colleges regulated in the Higher Education Law No. 2547, defined as; "It is a higher education institution that aims to train qualified human resources for certain professions, which lasts two or three semesters per year for two years and gives associate degree." (YÖK, 2018). As stated in this definition, vocational colleges are part of higher education. Vocational colleges are also a valuable resource to meet the needs of intermediate and small sized enterprises. (Gençtürk et al., 2008, 210; Ulus et al., 2015, 177). Starting from this resource feature,

\footnotetext{
1 Presented at ERPA International Congress on Education 2018, on 28 June 2018, in Istanbul.

2 Ins., Kirklareli University, Babaeski Vocational College, Finance, Banking and Insurance Department, ituzun@hotmail.com

3 Assoc. Prof. Dr., Kirklareli University, Science and Literature Faculty, Educational Sciences Department, ertugcan@gmail.com

${ }^{4}$ Ins, Kirklareli University, Babaeski Vocational College, Foreign Trade Department, oya.aktas@,klu.edu.tr 
Tuzun Arpacioglu, I., Can, E., \& Aktas, F. O. (2019). Evaluating the open admission practice in vocational colleges (Kirklareli University case). Journal of Human Sciences, 16(1), 205-215. doi:10.14687/jhs.v16i1.5470

vocational colleges are defined as "higher education institutions that provide intermediate human power with the title of technician and professional staff" (Kızgin, 2005, 120) or "institutions that provide education and training for a certain profession aimed at raising qualified human power" (Erdönmez, 2017, 57).

In the Turkey's Tenth Development Plan (2013, 203-204), it is stated that the students' success remained below the international average, there is a need to improve the quality, training of qualified human power is needed to ensure the development in the long term in Turkey. Procedures preferred for student admission to vocational colleges differed over time. In this research, the educational effects of the recent legislative changes on the system adopted at the vocational colleges have been tried to be evaluated within the framework of the opinions of the instructors of the vocational colleges of Kirklareli University.

Open admission practice was accepted in 2001. It has been stated that the students who graduated from vocational and technical secondary education institutions who want to enter a higher education program not covered by vocational and technical education zones continue to have the right to enter the university entrance examination. Within the scope of the regulation, "the possibility of placement without taking a national examination to the higher education institutions brought to the students graduated from vocational and technical secondary education institutions" has been integrated with the name of "open admission practice". With this changes of the implementation "significant achievements in vocational and technical education in Turkey will be taken and ultimately, to achieving results in the reform of qualifications in vocational and technical education" had been hoped (YÖK, 2004, 73). The implementation started in the 2002-2003 academic year and the graduation years, duration of education, school types, vocational and technical education zones, vocational secondary school achievement scores, preferences and quotas were taken into consideration. However, this practice has been criticized in the first years for not having any predictions of how to solve the problem of unemployment of graduates and has been predicted to be "problematic" because it was dealt with coping the numerical pressures in higher education (Akpinar, 2003, 23). In a study in which the open admission practice was evaluated, it was determined that the students do not make enough efforts to gain knowledge and skills, since they would enter the vocational college with open admission practice, the students who did not acquire sufficient knowledge and skills from vocational and technical secondary education lowered the success in the vocational colleges and decreased the qualification and number of students in vocational colleges (Tunç, 2005, 80). In a study conducted on students in the third year of the open admission practice, $61.1 \%$ of the students reported that the system was not beneficial and should be abolished (Henden, 2006, 164-165). According to the findings of Nartgün and Yüksel (2009), there should be not to vocational colleges open admission practice. Because, according to the findings of Alkan, Suiçmez, Aydınkal \& Şahin (2014), the application of open admission practice negatively affects the quality of education in vocational schools. Similarly, according to Sönmez (2008), the open admission practice decreases student success in vocational schools. Therefore, Vocational colleges of higher education should be restructured as training centers parallel to the the principles of lifelong learning. Parallel to these findings, it is stated in the Tenth Development Plan that under the heading of educational policies, the secondary and tertiary education system will be brought to a process-oriented evaluation structure with the support of effective guidance and guidance services considering the interests and abilities of students (Tenth Development Plan, 2013, 32).

"Open admission practice" which had been going on for fifteen years, was abandoned in 2016 and replaced with "additional points system" (Yıldırım \& Çarıkçı, 2017). With this application, if students are placed in vocational program in the areas of their secondary education graduation, they get additional placement points by multiplying the secondary achievement score by 0,06 (YÖK, 2016, 22). 
Tuzun Arpacioglu, I., Can, E., \& Aktas, F. O. (2019). Evaluating the open admission practice in vocational colleges (Kirklareli University case). Journal of Human Sciences, 16(1), 205-215. doi:10.14687/jhs.v16i1.5470

There are different investigations related to the open admission practice. These studies were conducted according to the views of the students. However, this research was conducted according to the opinions of the academicians. There is not enough research on this subject based on the opinion of academicians. For this reason, this research is of great importance.

The aim of this research is to evaluate the open admission practice according to the opinions of the academicians.

\section{Method}

This study was designed in a case study model. A case study model is one of the qualitative research methods. The qualitative method is used to obtain in-depth and comprehensive information on a topic (Denzin and Lincoln, 2005; Patton, 2014).

\subsection{The research question}

The research question is formulated as "How do the academic staff evaluate the open admission practice in vocational colleges?" and the following questions were searched for answers: 1. What is the level of knowledge of academic staff about the open admission practice in vocational colleges?

2. What are the opinions of the academic staff regarding the elimination of the open admission practice?

3. According to the opinions of the academic staff, what are the differences between the students who come with the open admission practice and the ones who took the national exam?

\subsection{Data collection}

Qualitative method was used in the research. A purposeful sampling method was used to identify the participants. Purposive sampling allows for in-depth study of situations that are thought to have rich knowledge. Qualitative research data were obtained in written form with the participation of 29 instructors using structured interview form consisting of 4 open ended questions and evaluated with the help of content analysis. Within the scope of the research, they were asked their personal information such as age, sex, duration of experience, as well as whether they were aware of "open admission practice". In the second part of the survey, participants were asked to compare the elimination of the open admission practice, to evaluate the students in terms of employability, and to compare the students who took the national placement exam and the students who are placed with the open admission practice.

Qualitative research is a type of research in which data collection techniques such as observation, interview and document analysis are used, and a process is pursued to reveal perceptions and events in a natural and realistic way. Qualitative research patterns provide a flexible approach to the researcher and contribute to the coherence of the various stages within a given focus (Yildirim and Simsek, 2006). In the analysis of the qualitative data, content analysis based on coding was conducted. The basic process in content analysis is to bring together similar data within the framework of certain concepts and themes and to interpret them in a way that the reader can understand (Yildirim and Şimşek, 2006). In the method of content analysis; data gathered from written or verbal expressions are coded and classified in a systematic manner, and following that the correlations among data are established, it is attempted to realize the statistical inference (Marvasti, 2004).

In the analysis of the qualitative research data, each participant was given a number and coding. To provide reliability in the presentation of research findings, direct quotations were made from participant opinions, stating as K1, K5 etc.

\subsection{Validity and Reliability}

To ensure the internal validity: data were interpreted considering associated situation, the internal consistency of the sub-themes were supported based on the measures which internal homogeneity and external heterogeneity. Besides, the sub-themes were determined depending on theoretical structure, and all findings were presented without comment to ensure internal reliability (Creswell, 2015). Additionally, it was applied to the experts' opinion in order to verify whether the 
Tuzun Arpacioglu, I., Can, E., \& Aktas, F. O. (2019). Evaluating the open admission practice in vocational colleges (Kirklareli University case). Journal of Human Sciences, 16(1), 205-215. doi:10.14687/jhs.v16i1.5470

opinions represent sub-themes. In addition, the research model, study group, data collection tool and data analysis processes were given in detail to ensure the external validity of the study. Besides, the procedure was specified, in detail for each sections to ensure the external reliability of the study: the procedures include data collection, data analysis, consolidation and presentation of results, the topic, and the method. In order to ensure the reliability, all data were coded by the three researchers. On the codifications made by the researchers, the formula of Reliability = Consensus / (Consensus + Dissensus) X 100 (Miles \& Huberman, 1994) was applied. Matching percentage of the three codifications made was calculated as $87 \%$.

\subsection{Working Group}

The research was carried out in the spring semester of 2017-2018 academic year with the participation of faculty members of Vocational Colleges of Kirklareli University. 29 instructors participated in the study. According to the research findings, 16 of the 29 participants were male and 13 were female (Table 1). 27 of the participants are instructors and 2 are assistant professors (Table 2). Participants' average duration of work as an academician is 7 years.

Table 1. Gender of participants

\begin{tabular}{llc}
\hline Gender & Freq. & \% (Appr) \\
\hline Male & 16 & 55 \\
Female & 13 & 45 \\
Total & $\mathbf{2 9}$ & $\mathbf{1 0 0}$ \\
\hline
\end{tabular}

Table 1 shows the distribution of participants by gender. The number of male participants is 16 and the number of female participants is 13 . It can be said that participation in the survey is represented in equal place in terms of gender.

Table 2. Academic title of participants

\begin{tabular}{lcc}
\hline Academic Title & Freq. & \%(Appr) \\
\hline Teaching Assistant & 27 & 93 \\
Assistant Professor & 2 & 7 \\
Total & $\mathbf{2 9}$ & $\mathbf{1 0 0}$ \\
\hline
\end{tabular}

Table 2 shows the distribution of participants by academic title. 27 participants are teaching assistant and 2 participants are assistant professors. This high rate of instructors is a parallel indicator that most of the academic staff in vocational colleges consist of instructors.

Table 3. Administrative duty of participants

\begin{tabular}{lcc}
\hline Administrative duty & Freq. & \% (Appr.) \\
\hline Department Head & 3 & 10 \\
Deputy Headmaster & 1 & 4 \\
None & 25 & 86 \\
Total & $\mathbf{2 9}$ & $\mathbf{1 0 0}$ \\
\hline
\end{tabular}

Table 3 shows a distribution of participants' administrative duties. Participants include only 1 deputy headmaster (4\%) and 3 department heads (10\%). 25 of the participants $(86 \%)$ do not have any administrative duties. To investigate the evaluations of academic staff with administrative duties, it is expected that they will make contributions in terms of procedures/principles and implementation. 
Tuzun Arpacioglu, I., Can, E., \& Aktas, F. O. (2019). Evaluating the open admission practice in vocational colleges (Kirklareli University case). Journal of Human Sciences, 16(1), 205-215. doi:10.14687/jhs.v16i1.5470

\section{Findings}

According to findings, 9 of the respondents described the elimination of the open admission practice negatively, while 20 considered the abolition of implementation as positive. Regarding the effect of the elimination of the open admission practice on employability, 16 participants stated that it would affect positively, 6 of them said it would have a negative impact, and 7 participants stated that it would have no effect on employability.

According to the findings of the research, 3 of the participants stated that the students those who did not take the exam were more successful than the ones who did, 17 of the participants stated that the students who are placed in the vocational college by being successful in the national exam were more successful, and 9 of the participants stated that there was no difference between the students. As a result, 20 participants evaluated the elimination of the open admission practice as positive in general terms, 17 participants evaluated it as positive considering the quality of education and 16 participants evaluated it as positive in terms of employability.

\subsection{Participants' Opinions about the Removal of Open Admission Practice}

In the second part of the survey, participants were requested to evaluate their general opinions of the elimination of the open admission practice enabling students to pass from the secondary education to the higher education in terms of employability and to evaluate the differences between the students who passed the national central exam and the students who enrolled with open admission practice. In addition, other opinions about the related subject were also asked.

\subsubsection{General evaluations on the elimination of the open admission practice to transfer from secondary education to tertiary education}

Participants evaluated positively the elimination of the open admission practice by a high majority (20 persons). The base of this opinion is the thought that the qualifications and the successes of the vocational college students will be increased with the help of increased number of students who took the national central exam.

However, the participants who found cancelation of the open admission practice as negative ( 9 participants) base their opinions on the decrease of the number of students in general (K24, K27), the decrease of department quotas (K19) and the fact that those who have not received secondary education in the related profession are not interested in the related departments curriculum (K7). Interestingly, according to one participant's opinion, "The right granted to them for vocational training development by vocational high school students has been withdrawn" (K29).

Table 4. Participants' views about the removal of open admission practice

\begin{tabular}{lccc}
\hline Opinion & Positive & Negative & Ineffective \\
\hline General view & 20 & 9 & 0 \\
Effect on employability & 16 & 7 & 6 \\
\hline
\end{tabular}

When Table 4 is examined, it is seen that the participants' views on the open admission practice as positive, negative and ineffective. When the general opinions of the participants regarding the elimination of the open admission practice were examined, it was found that a large part (20 participants) of the participants see it as positive, while the other participants ( 9 participants) stated that it is negative to eliminate the open admission practice.

Participants stated that it is positive to remove the open admission practice by $69 \%$ (20 participants). The views of some participants on this idea are as follows:

"T evaluate it positively. I am not a fan of old system" (K2),

"I thought it was absolutely necessary to be removed. It is a positive development for the universities. I think that the quality will increase (in terms of student profile). I believe that the goal is to get the students who really come to achieve their goals." (K4),

"I find it positive. It has been observed that the system applied in the past reduced the quality in the relevant sections. First, the student does not see the place where s/ he has come to be. Considering the quality of high school system in Turkey, it is a success. The problem of low success rates in high school is causing the inferior success rates in 
Tuzun Arpacioglu, I., Can, E., \& Aktas, F. O. (2019). Evaluating the open admission practice in vocational colleges (Kirklareli University case). Journal of Human Sciences, 16(1), 205-215. doi:10.14687/jhs.v16i1.5470

the higher education. Therefore, the rate of low levels of a certain age and knowledge, cognitive level, reduce the level of the department of higher education." (K10),

"The removal of the application is the right decision. The higher education level of the students who come with the exams will increase the overall success levels." (K13),

"I find it as the right decision. During the transition period, the student population had a very low level of knowledge and a very low level of success rates. I now observe that the relative readiness of the students is high" (K15).

On the other hand, when the participant's views on the effect of the elimination of open admission practice on the employability are examined, 16 participants gave a positive opinion and 7 gave a negative opinion; whereas the 6 of them stated that elimination of the open admission practice would not have any effect on employment.

\subsubsection{Evaluation of the elimination of the open admission practice from secondary education to tertiary education in terms of employability}

Table 5. Evaluation of the elimination of the open admission practice from secondary education to tertiary education in terms of employability

\begin{tabular}{lcc}
\hline Opinion & Freq. & \%(Appr.) \\
\hline Positive & 16 & 55 \\
Negative & 7 & 24 \\
Ineffective & 5 & 17 \\
No opinion & 1 & 4 \\
Total & $\mathbf{2 9}$ & $\mathbf{1 0 0}$ \\
\hline
\end{tabular}

In Table 5 it is seen that the participants declare their opinion on the effect of elimination of the open admission practice from secondary to higher education on the employability as basically as "positive, negative and ineffective" and 1 person does not declare any opinion on the subject.

It appears that 16 of the participants $(55 \%)$ said that abolishing the open admission practice would positively affect employability, and 7 of the participants $(24 \%)$ said it would negatively affect employability. In addition, 5 people $(17 \%)$ said eliminating the open admission practice would have no effect on employability.

Participant with positive opinions about the effects of the abolition of the open admission practice are presented in Table 6.

Table 6. Opinions of those who find it positive to eliminate the practice of open admission.

\begin{tabular}{|c|c|}
\hline 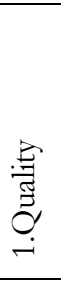 & $\begin{array}{l}\text { - The number of qualified staff to be employed increases, qualified staff to be trained (K1). } \\
\text { - As the quality increases, employment rate also increases (K5). } \\
\text { - More qualified employees can be trained (KO). } \\
\text { - The sectors in the market will be provided with more qualified and trained graduates (K15). } \\
\text { - I think the number of students will be more positive in terms of proficiency (K18). } \\
\text { - As the quality increases, employment also increases (K21). } \\
\text { - I think it will result in qualified staff. At least the percentage of graduates who are unemployed will decrease (K25). }\end{array}$ \\
\hline 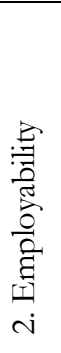 & $\begin{array}{l}\text { - As the quality increases, employment rate also increases (K5). } \\
\text { - Since the students are more successful, their chances of being employed may increase (K11). } \\
\text { - The direct effect of hiring is the issue. In this respect, students who receive enough points from the test technique can work in } \\
\text { different fields on sectoral basis by taking training (K14). } \\
\text { - As the quality increases, employment also increases (K21). } \\
\text { - I think that the students who are studying on a regular basis have a high success rate and therefore will have a positive } \\
\text { impact on finding a job and working (K23). } \\
\text { - The employability of the student who enrolled in the vocational college with taking the national central exam may be higher } \\
\text { (K26.) }\end{array}$ \\
\hline
\end{tabular}

As seen in Table 6, participants assessed the positive effects of the elimination of the open admission practice under two headings: quality and employment. 
Tuzun Arpacioglu, I., Can, E., \& Aktas, F. O. (2019). Evaluating the open admission practice in vocational colleges (Kirklareli University case). Journal of Human Sciences, 16(1), 205-215. doi:10.14687/jhs.v16i1.5470

\subsubsection{Evaluation of the differences between the students who pass the national central exam and the students who enrolled with the open admission practice}

Table 7. Evaluation of the academic achievements of the students who enrolled with the open admission practice

\begin{tabular}{lcc}
\hline Opinion & Freq. & \%(Appr.) \\
\hline Successful & 3 & 10 \\
Unsuccessful & 17 & 59 \\
Same & 9 & 31 \\
Total & $\mathbf{2 9}$ & $\mathbf{1 0 0}$ \\
\hline
\end{tabular}

In Table 7, it was seen that the participants expressed their opinions about the academic success of the students who enrolled with the open admission practice as "successful, unsuccessful and same". It is seen that 3 of the participants $(10 \%)$ see the students who enrolled with the open admission practice as more successful than the students who took and passed the national central exam, whereas $17(59 \%)$ of the participants see them as more unsuccessful. In addition, 9 participants $(31 \%)$ stated that there was no difference in success rates among the students. As you can see, the participants generally find students unsuccessful who enrolled with the open admission practice.

Table 8 lists the participants' views about the differences between the students who pass the examination and the students who did not take the exam by evaluating the in class achievements of the students.

Table 8. Evaluation of the differences between the students who came with the exams and who came without the exams, according to their in class achievements

\begin{tabular}{|c|c|}
\hline $\begin{array}{l}\text { 1. Students who come } \\
\text { without taking an exam } \\
\text { are more successful in } \\
\text { their lessons/more } \\
\text { interested in the lessons. }\end{array}$ & $\begin{array}{l}\text { - We saw that the students who came without an exam were more related to the } \\
\text { department. Other students were unwilling. They had no goals (K6). } \\
\text { - Students who came without an exam are more interested (K7). } \\
\text { - Students who came with an exam are not interested in the field. Students who did } \\
\text { not take departmental courses before, are less interested in classes (K20). }\end{array}$ \\
\hline $\begin{array}{l}\text { 2. Students who take the } \\
\text { exam are more } \\
\text { successful in their } \\
\text { lessons/more interested } \\
\text { in the lessons. }\end{array}$ & $\begin{array}{l}\text {-The students who come with the exam are more qualified, at least they are more } \\
\text { attentive because they make more effort (K1). } \\
\text {-The students who come without exam come as lacking the most basic knowledge and } \\
\text { responsibilities. The students who come with the exam are those who bave better } \\
\text { quality of education and worry about the future than the others (K2). } \\
\text {-I see that the students who take the exam are more responsible and their grades are } \\
\text { higher (K4). } \\
\text { - Learning and comprehension is better in students who come with the exam (K5). } \\
\text { - Knowledge level, self-discipline, level of success attributed to students, tends to be low } \\
\text { in students who come without the exam (K8). } \\
\text { - I find the students who come with the exam more successful. They are target oriented } \\
\text { (K11). } \\
\text { - Those who come to the exam are more interested, they have goals (K16). } \\
\text { - In terms of quality and willingness, students who come with the exam are better } \\
\text { (K23). } \\
\text { - The student who come with the exam is more aware of the needs of the profession } \\
\text { (K26). } \\
\text { - I can indicate that the academic achievements of the students who come without } \\
\text { taking the exam are low, especially according to the results of the assessment and } \\
\text { evaluation. They have difficulties in expressing themselves in writing and in exams, } \\
\text { especially on the multiple choice tests (K29). }\end{array}$ \\
\hline
\end{tabular}


Tuzun Arpacioglu, I., Can, E., \& Aktas, F. O. (2019). Evaluating the open admission practice in vocational colleges (Kirklareli University case). Journal of Human Sciences, 16(1), 205-215. doi:10.14687/jhs.v16i1.5470

\begin{tabular}{|l|l|}
\hline $\begin{array}{l}\text { 3. There is no difference } \\
\text { between the students }\end{array}$ & - This difference has not yet appeared (K3). \\
who come with the exam & - I did not notice any obvious difference (K12, K13, K24). \\
and the ones who come & - There are no major differences in performance (K14). \\
without taking the exam. & - There is no difference (K19). \\
& - I do not see any difference between students in vocational colleges (K27). \\
& $\begin{array}{l}\text { - It may be early to make an assessment because it is the first year of the } \\
\text { implementation. However, I did not notice a significant difference compared to the } \\
\text { general student level in the past years in the classes I entered for this year (K28). }\end{array}$ \\
\hline
\end{tabular}

As seen in Table 8, the participants made assessments on the differences between the students who came without examination and the students who came with the exam. The participants who made these evaluations according to the achievement of the students' interest in the lessons stated three different opininons: 1 . the students who did not take the exam were more successful and related to the field, 2. the students who came with the exam were more successful and interested and 3. They did not see any difference between them. Some participants commented that it was too early to make an assessment because it was the first year of implementation (K18 and K28).

When the participant's assessment of the subjects related to the open admission practice was examined, 10 participants made additional comments on the subject. Three of these participants expressed their views clearly as following statements: "I wish for the return to the old system" (K6), "Lets go back to the open admission practice" (K7) and "Open admission practice should go on" (K20). 1 participant wrote "I think it was an opportunity for students to come to vocational college without taking an exam" (K27), favoring the open admission practice. 3 of the participants wrote, "I support the system with the exam as the must" (K21), "I hope we do not return to the old system" (K22), "We should continue with the new system" (K3). 1 participant said, "With the removal of the open admission practice, now it would have been much more effective than the old form but if it were in the form of a "soft transition" that would be carried out over a large scale and spread over time, where all of the institutions involved would be a better option" (K28), suggesting a softened transition model.

\section{Discussion, conclusion and recommendations}

According to the findings of the research, there are three important results about the removal of the examination without examination. Participants see the removal of the open admission practice as a positive practice. According to the findings of the research, it is parallel to many other studies that participants express positively the elimination of the open admission practice. For example, in a study on vocational education in health services, "the re-examination of the open admission practice" applied for student acquisition is recommended (Bostan, 2007, 27). In a similar study evaluating the views of administrators and teachers working in high schools, it was considered a good decision to abolish the open admission practice (Yıldırım \& Çarıkç1, 2017, 211). In another study where the quality of vocational colleges was assessed against the open admission practice, it was proposed to reconsider changes in the old system at the university entrance practices (Odabaş1, 2013, 283). In both two research, it is seen that the open admission practice is evaluated negatively. In another parallel study (Henden, 2006, 164-165) in which the open admission practice was assessed by vocational school students', $68.1 \%$ of the students who participated in the research indicated that the system was not beneficial and should be abolished. In addition, research findings of Odabaş1 $(2013,283)$ and Bostan $(2007,27)$ which stated the enrolling system to the universities should be reconsidered, support our findings.

However, the participants who found cancelation of the open admission practice as negative base their opinions on the decrease of the number of students in general, the decrease of department quotas and the fact that those who have not received secondary education in the related profession are not interested in the related departments curriculum. In a similar study (Yildirim \& 
Tuzun Arpacioglu, I., Can, E., \& Aktas, F. O. (2019). Evaluating the open admission practice in vocational colleges (Kirklareli University case). Journal of Human Sciences, 16(1), 205-215. doi:10.14687/jhs.v16i1.5470

Çarıkç1, 2017, 214), 40,85\% of the administrators and teachers in the high schools stated that "the application of the additional points would decrease the number of vocational and technical high school students who go on their education with a higher degree and this would cause department quota vacancies in the colleges." In addition, according to Demir (2018), only 13\% of students want the open admission practice to be abolished. In other words, the majority of the participants would like to continue the open admission practice.

According to the majority of the participants, the removal of the open admission practice positively affects employability and quality. From this point of view, the fact that the vocational colleges can not respond to the needs of the sector from time to time during the period of open admission practice is declared by the business community (Erdönmez, 2017, 57) supports the findings of the research.

Finally, in comparison between the students who come with the exam and who doesn't, most of the participants find that the students who come without the exam are more unsuccessful than the students who come with the exam with $59 \%$. The students who come with the exam are more successful. According to the findings of Kelecioglu (2006), students attending vocational colleges's without taking OSS (Student Selection Exam) fail in more courses in the first year than the students that have taken OSS.

In the findings of Aşlioğlu et al. (2016, 87), it was stated that the students who came to the vocational college by passing the national central exam, complete the school in a shorter period with a higher GPA. The finding that most of the participants think that the students who settled in the vocational college with the open admission practice are more unsuccessful than the students who took the exam, are supported by different research findings in the literature. According to the findings of Kizgin $(2005,126)$, the success of the students who come to the vocational college with the open admission practice is lower than the students who came with the exam. According to the findings of Çağlar \& Türeli (2005, 372-375), the success averages of the students who came to the vocational college were higher than those who did not pass the exam. According to the findings of Demirbulat et al. $(2017,120)$, the GPA of students who are enrolled with the national central exam result have higher GPAs. According to the findings of Bostan (2007, 26-27), the successes of the students who are enrolled with the open admission practice were found to be significantly lower this constitutes a problem in terms of the success of health services vocational colleges. In the findings of Aşlloğlu et al. (2016, 87), it was determined that the students who came to the vocational college completed the school in a shorter period with a higher GPA. According to Karagül et al.(2011), it decreases the quality of education and training of students attendance to vocational schools without examination. Therefore, the open admission practice should be removed from vocational colleges. According to findings of Sönmez (2008), the open admission practice decreases student success in vocational schools.

In addition, it is observed that the students who came through the central university exam all over the 15 years are more successful than the students who settled with the open admission practice (Erdönmez, 2017, 58) and the students who settled with the open admission practice are less successful in the mathematics than the students who took the national central exam and that the ratio of the students who did not take the examination was higher than the students who did not take the exam and moreover, the ratio of the course repetition is higher in the students who settled in vocational colleges with the open admission practice (Durukan et al., 216) and all these research findings support our research findings. However, Kuşat's finding $(2014,77)$ which stated that it does not make a difference between the successes of students coming to vocational colleges with or open admission practice is not like this research findings.

The research findings show that eliminating the open admission practice is a positive practice. Considering that the needs and expectations of the society and the labor market have changed in the face of the changing and developing technology, it is expected that in the coordination of the Ministry of National Education and the Higher Education Council, in the important structural system changes, especially the education policies applied/planned to be applied for secondary 
Tuzun Arpacioglu, I., Can, E., \& Aktas, F. O. (2019). Evaluating the open admission practice in vocational colleges (Kirklareli University case). Journal of Human Sciences, 16(1), 205-215. doi:10.14687/jhs.v16i1.5470

education and higher education, cooperation with higher education institutions, students, parents, non-governmental organizations, teachers, administrators, field specialists and labor market will be more beneficial to make pilot research data and regulations based on community needs and expectations.

\section{References}

Alkan, R. M., Suiçmez, M., Aydınkal, M. \& Şahin, M. (2014). Meslek yüksekokullarındaki mevcut durum: Sorunlar ve bazı çözüm önerileri [Current situation in vocational schools: Issues and some suggested solutions]. Yüksekögrretim ve Bilim Dergisi/Journal of Higher Education and Science, 4 (3), December 2014; 133-140.

Akpınar, B. (2003). Meslek yüksekokullarına sınavsız geçiş [Open admission in vocational colleges]. Kuram ve Uygulamada Eğitim Yönetimi, 33, 8-25.

Aşılıoğlu, F., Çay, R. D. \& Şanlıbaba, P. (2016). Kalecik Melsek Yüksekokulu öğrencilerinin başarı düzeylerinin bazı değişkenler açısından incelenmesi [Examining the success level of the students of Kalecik Vocational College in terms of some variables]. Electronic Journal of Vocational Colleges, 79-88.

Bostan, S. (2007). Sağlık hizmetleri meslekî eğitiminde sınavsız geçiş sorun mu? [Is the open admission a problem in health services education ] Tip Eğitimi Dünyası, 23-27.

Creswell, J. W. (2015). Nitel arasstrma yöntemleri [Qualitative research methods] (M. Bütün \& S. B. Demir, Trans. Eds.). Ankara: Siyasal.

Çağlar, N. \& Türeli, N. (2005). Meslek yüksekokullarına sınavsız geçişle ve ÖSS puanı ile gelen öğrencilerin genel başarı oranlarının karşılaştırılması [Comparison of the overall success rates of students enrolled in the vocational colleges with or without taking the national exam]. Süleyman Demirel Üniversitesi İktisadi ve İdari Bilimler Fakülttesi, 10(2), 369-377.

Demir, Ü. (2018). Meslekî ve teknik anadolu lisesi öğrencilerinin meslek yüksekokulu özelinde yükseköğrenim tercihlerinin incelenmesi: Çanakkale İli Mesleki ve Teknik Anadolu Lisesi 12. sınıf öğrencileri üzerine bir araştırma [Examination of higher education preferences of vocational and technical anatolian high school students: A research on 12th grade students Vocational and Technical Anatolian High School in Çanakkale City]. Selcuk Üniversitesi Sosyal Bilimler Meslek Yükesekokulu Dergisi, 21 (2), November 2018, 132-148.

Denzin, N. K., \& Lincoln, Y. S. (2005). The sage handbook of qualitative research. California: Sage Publications.

Durukan, S., Aygün, M., Aydın, İ. \& Diril, H. Z. (2015). Meslekî ve teknik eğitimde sınavsız geçişle ve sınavla gelen öğrencilerin matematik başarılarının değerlendirilmesi [Evaluation of mathematics achievement of students who enrolled with or without national exam]. Eğitim ve Öğretim Arasstrmalar Dergisi, 4(3), 211-218.

Erdönmez, C. (2017). Önlisans programlarına yerleştirilen öğrencilerin yerleştirilme biçimlerine göre başarı oranlarının karşılaşturlması, Çanakkale örneği [Comparison of the success rates of students enrolled in associate degree programs, Çanakkale case]. Electronic Journal of Vocational Colleges, 52-59.

Gençtürk, M., Demir, Y. \& Çarıkçı, O. (2008). Meslek yüksekokulu öğrencilerinin muhasebe-finans eğitimine bakış açıları ve farkındalıkları üzerine bir uygulama [An application on the viewpoints and awareness of accounting-finance education of vocational college students]. Süleyman Demirel Üniversitesi İktisadi ve İdari Bilimler Fakültesi, 13(1), 209-228.

Güdü Demirbulat, Ö., Saatcı, G. \& Seyfioğlu, E. (2017). Sınavlı ve sınavsız geçiş ile meslek yüksekokullarına yerleşen öğrencilerin başarı durumlarının incelenmesi [Examining the success level of students enrolled in vocational colleges with or without exam]. Journal of Current Researches on Social Sciences (JoCReSS), 7(3), 115-124.

Henden, R. (2006). Üçüncü yılda sınavsız geçiş uygulamaları: Alaplı Meslek Yüksekokulu örneği [Third year examination without exam: Alaplı Vocational College case]. ZKÜ Sosyal Bilimler Dergisi, 2(4), 157-168.

Karagül K., Karagül N. \& Doğan M. (2011). Sınavlı ve sınavsız geçiş için akademik bir karşılaştırma [Comparison for transition with examination and without examination]. II. Uluslararasi, VI. Ulusal Meslek. Yüksekokullar Semposyumu, Aydın, 25 -27 Mayıs 2011; 1:1-5.

Kelecioğlu, H. (2006). Meslek yüksekokullarına sınavsız geçiş sisteminde öğrenci başarısına ilişkin öğrenci ve öğretim elemanlarının görüşleri [Opinions of the students and lecturers about the student achievement in the system of attendance to vocational colleges without examination]. Eurasian Journal of Educational Research (EJER). July 2006, Issue 24, p123-133. 11p. 
Tuzun Arpacioglu, I., Can, E., \& Aktas, F. O. (2019). Evaluating the open admission practice in vocational colleges (Kirklareli University case). Journal of Human Sciences, 16(1), 205-215. doi:10.14687/jhs.v16i1.5470

Kızgın, Y. (2005). Sınavsız geçiş (METEB) sistemi ile gelen öğrencilerin başarılarının istatistiki analizi: Muğla Üniversitesi Muğla Meslek Yüksekokulu örneği [Statistical analysis of the success of the students enrolled with open admission practice: Muğla University Muğla Vocational College case]. "İ̧s, Gü̧s" Endïstri Iliskileri ve İnsan Kaynaklar Dergisi, 7(2), 119-129.

Kuşat, N. (2014). Meslek yüksekokullarında öğrenci başarısı üzerine bir çalışma: Eğirdir Meslek Yüksekokulu Muhasebe Programı örneği [A study on student achievement in vocational colleges: Eğirdir Vocational College Accounting Program case]. Muhasebe ve Finansman Dergisi, 65-79.

Marvasti, A.B. (2004). Qualitative research in Sociology: An introduction. SAGE Publications. Inc.

Miles, M. B., \& Huberman, A. M. (1994). Qualitative data analysis: An expanded sourcebook. (2nd ed.) Thousand Oaks, CA: Sage.

Nartgün, S.. \& Yüksel, E.(2009). Meslek yüksekokullarına sınavsız geçişte izlenen kriterlerin degerlendirilmesi [Evaluation of criteria used to vocational high schools placement without the student selection and placement system]. Abant İzet Baysal Üniversitesi Dergisi. 9(2), 189-205.

Odabaşı, B. (2013). Mesleki ve teknik ön lisans programlarında kalite arayışı: Sınavsız geçiş [Search for quality in vocational and technical associate degree programs: Open admission practice]. C.U.U. Sosyal Bilimler Enstitiisï Dergisi, 22(2), 269-286.

Patton, M. Q. (2014). Nitel arasterma ve değerlendirme yöntemleri. [Qualitative evaluation and research methods]. (M. Bütün \& S. B. Demir, Trans. Eds.) Ankara: Pegem Akademi.

Sönmez, M. (2008). Türkiye'de mesleki ve teknik örgün öğretimin sorunları ve yeniden yapılandırllma zorunluluğu. [The Problems of Vocational and Technical Education in Turkey and the Necessity of Restructuring]. Education and Science. 33 (147), 71-84.

T.C. Kalkınma Bakanlı̆ı. (2013). Onuncu Kalkemma Plam 2014-2018 [Tenth Development Plan 2014-2018]. Retrieved 02/07/2018, from http://www.kalkinma.gov.tr/Lists/Kalknma\%20Planlar/Attachments/12/Onuncu_Kalk\%C4\%B1 nma_Plan $\%$ C4\%B1.pdf.

T.C. Yükseköğretim Kurulu (2004). Meslek yüksekokullarnn bugünkü durumu ve meslek ve teknik orta ögretim okullarndan meslek yülksekokullarnna sinavsiz geçisin değerlendirilmesi [The current status of vocational colleges and the evaluation of the open admission practice, from vocational and technical secondary schools to vocational colelges]. Ankara.

Tunç, A. (2005). Yüksekokullarına sinavsız geçişin değerlendirilmesi [Evaluation of open admission practice]. ZKÜ Sosyal Bilimler Dergisi, 1(2), 75-81.

Ulus, L., Tuncer, N. \& Sözen, Ş. (2015). Mesleki eğitim, gelişim ve yeterlilik açısından meslek yüksekokullarının önemi [The importance of vocational colleges in terms of vocational education, development and qualificaiton]. Uluslararası Türk Eğitim Bilimleri Dergisi, 168-184.

Yıldırım, A. \& Şimşek, H. (2006). Sosyal bilimlerde nitel araștrma yöntemleri [Qualitative methods in the social sciences]. Ankara: Seçkin Yayıncilık.

Yıldırım, A. \& Çarıkçı, O. (2017). Meslek yüksekokullarında belirsiz gelecek: Sınavsız geçişten ek puana. Yöneticilerin ve öğretmenlerin, MYO’ların geleceği hakkındaki görüşlerinin değerlendirilmesi [Uncertain future in vocational colleges: From open admission to additional points. Evaluation of the opinions of the managers and teachers about the future of vocational colleges]. Mehmet Akif Ersoy Üniversitesi Sosyal Bilimler Enstitïsï Dergisi, 9(21), 203-218.

Yükseköğretim Kurulu (YÖK). (2018). 2547 Sayll Yüksekögretim Kanunu [Higher Education Law No. 2547]. Retrieved $20 / 05 / 2018$

from http://www.yok.gov.tr/documents/10279/29816/2547+say\%C4\%B11\%C4\%B1\%20Y\%C3\%BCk sek $\% \mathrm{C} 3 \% \mathrm{~B} 6 \% \mathrm{C} 4 \% 9$ Fretim+Kanunu/

Yükseköğretim Kurulu (YÖK). (2010). Bologna Süreci [Bologna Process]. http://www.yok.gov.tr/web/uluslararasi-iliskiler/bologna-sureci adresinden 21.06.2018 tarihinde alınmıştır.

Yükseköğretim Kurulu (YÖK). (2016). Sınavsız geçişin kaldırılması ve yeni katsayı uygulaması. [Removal of the open admission and application of new coefficients]. http://yok.gov.tr/web/guest/duyuru adresinden 14.07.2018 tarihinde alınmıştr. 